\title{
Effect of some Biotic and Abiotic Applications on Control of Fusarium Wilt of Pepper Plants \\ A.
}

N.M. Abou-Zeid, Noher

Plant Pathol. Res. Inst., ARC, Giza, Egypt.

Gix different pathogenic isolates of Fusarium oxysporum were $\checkmark$ recovered from diseased pepper plants collected from Dakahlya and Gharbya governorates, in Egypt. The F3 isolate of $F$. oxysporum recovered from Dakahlya samples was more aggressive hence produced $96.67 \%$ wilt severity, that being significantly higher than Tanta isolate F4 producing $71.67 \%$ severity. Remarkable variation in wilt producing potentials was found among other isolates denoting different pathogenic capabilities. Chemical substances inducing plant resistance against $F$. oxysporum were checked for their effect on linear growth of the pathogen. Dipotassium phosphates, potassium sorbate, salicylic acid, ascorbic acid along with chitosan, clove oil, mint oil and cumin oil were evaluated. Trichoderma hamatum and T. harzianum were also considered. A positive relation between a given inducer and inhibition of fungal growth in vitro was concluded. However, clove oil at low concentration $(0.25 \%)$ inhibited completely the mycelial growth of pathogen, compared to other inducers that decreased the growth in a range between 42.2 and $91.9 \%$, for the low concentrations. In greenhouse trials, a significant reduction in wilt was recorded. Immersed seedlings in the selecting concentration of inducers, bioagents, biocides and Topsin M70 fungicide were compared. The most effective treatments were Bio-Zeid and salicylic acid giving a similar wilt severity (21.67\%), followed by ascorbic acid, Bio-Nagi, $T$. hamatum and $T$. harzianum that decreased severity in an ascending order from 26.67 to $43.33 \%$. Topsin M70 fungicide gave $16.67 \%$ wilt severity, being the best control treatment, compared to $91.67 \%$ for cumin oil that could be ignored. Field grown plants of pepper showed significant wilt decrease following application with salicylic acid and Bio-Zeid. Ascorbic acid and Bio-Nagi along with T. hamatum showed promising results. Moreover, application of salicylic acid and Bio-Zeid increased growth parameters. The study suggested that Bio-Zeid and salicylic acid were the most effective treatments for controlling wilt and increasing yield of pepper. Ascorbic acid, Bio-Nagi and $T$. hamatum were promising in this regard. Further investigations are needed.

Keywords: Bioagents, biocides, disease control, Fusarium wilt, resistance inducers and yield quality.

Pepper (Capsicum annum L.) is one of the most important vegetable crops in Egypt. Green and red fruits are used for fresh salad and food commodities containing proteins, vitamins (A and C), and minerals as calcium, phosphorous and irons (Chowdhury et al., 2015). Production has been hampered by many diseases of 
which Fusarium wilt caused by Fusarium oxysporum was reported by many investigators to cause great losses in pepper production in worldwide. The disease affects plant at all developmental stage causing wilt syndrome of many crops (Lefebvre and Palloix, 1996; Kucuk and Kivanc, 2003; Abdel-Monaim and Ismail, 2010). The total cultivated area with pepper in Egypt during 2013 reached about 65240 feddan with a total production of 387964 ton, at the rate of 5.95 ton/feddan. In addition, there exist approximately 1000 feddan in protected cultivation producing about 7500 ton with an average of 7.5 ton/feddan (The Yearly Book of Economics and Statistics of the Agriculture Ministry of Egypt, 2014). Though chemical control against such diseases sometimes gives good results, the use of fungicides leads mostly to environmental pollution and the phenomena of resistance to the plant pathogens (Brewer and Larkin, 2005). Biological control is considered an important approach of agricultural biotechnology in recent years for controlling many fungal plant pathogens (Zaher et al., 2013). Trichoderma spp. are a major mycoparasites which parasitize a large number of plant pathogens (Liu and Baker, 1980). They produce antimicrobial substances for control of many soil borne diseases such as Fusarium wilt of pepper (Hulang, 1980). Induction of resistance in plants to overcome pathogen infection is a promising approach for controlling plant diseases. Exogenous or endogenous factors could substantially affect host physiology, lead to rapid and coordinated activation of defense gene in plants normally expressing susceptibility to pathogen infection (Mandal et al., 2009 and Metwally, 2004). This induced resistance to pathogens can be achieved by the application of various abiotic agents, chemical inducers such as salicylic acid, potassium salts and ascorbic acid (El-Khallal, 2007; Abdel-Monaim, 2010; Akram and Anjum, 2011 and El-Mohamedy et al., 2013). Fortunately, application of such inducers under field conditions have increased growth parameters, yield components and quality of fruits in many vegetable plants (El-Mougy, 1995; El-Mougy et al., 2004; Karlidag et al., 2009 and Zahra et al., 2010).The present study was conducted to investigate the effect of some biotic and abiotic agents as resistance inducers in pepper plants against Fusarium wilt pathogen in vitro, in vivo and under field conditions and to elucidate their impacts on growth parameters and yield.

\section{Materials and Methods}

Isolation and identification of the causal pathogens:

Samples of wilted pepper plants were collected from different governorates in Egypt, washed under tap water and sterilized by immersing in $5 \%$ sodium hypochlorite for 2 minutes (Waller, 1981) and subsequently rinsed with sterile distilled water. Thin sections were placed on potato dextrose agar (PDA) medium in Petri dishes and incubated at $25 \pm 2{ }^{\circ} \mathrm{C}$, for five days. Each of the emerged fungi was picked up and purified by transferring the hyphal tip into PDA plates and identified according to their morphological features using the descriptions of Booth (1971) and Domsch et al. (1980) at the Unit of Identification of Micro-organisms, Plant Pathology Research Institute, A.R.C., Giza, Egypt. 
Pathogenicity test:

Six isolates were grown in autoclaved bottles $(500-\mathrm{ml})$ containing $(25 \mathrm{~g}$ clean sand and $75 \mathrm{~g}$ sorghum grains and sufficient amount of water to cover the mixture and autoclaved at $121^{\circ} \mathrm{C}$ for $30 \mathrm{~min}$ ) and incubated for 15 days at $25 \pm 2{ }^{\circ} \mathrm{C}$. Formalin sterilized pots $(20 \mathrm{~cm}$. in diameter) were filled with autoclaved clay soil and infested with pathogenic fungus at the rate of 5\% (Abou-Zeid et al., 2002). Three cultivars Anaheim-M of 35-day old pepper transplants grown in disinfested soil were used as control. The plants were left for three months after transplanting under greenhouse conditions at the Unit of Identification of Micro-organisms, Plant Pathology Research Institute, A.R.C. Giza, Egypt. The wilt disease severity was carried out using a visual 1-6 scale according to Silva and Bettiol (2005) as follows: $1=$ no symptom; $2=$ plant showed yellowing leaves, and wilting 1-20\%, 3= plant showed yellowing leaves, and wilting $21-40 \%, 4=$ plant showed yellowing leaves, and wilting $41-60 \%$, $5=$ plant showed yellowing leaves, and wilting $61-80 \%$ and $6=$ plant showed yellowing leaves, and wilting $81-100 \%$ or dead plant. Virulent group was categorized according to DSI as non-pathogenic (DSI $=1)$, low (DSI $\leq 3.50$ ), moderate (DSI > 3.50 - 4.50), and high (DSI > 4.50). The percentages of disease severity index (DSI) and disease reduction were determined using the formula:

DSI $(\%)=\sum$ (grade $\mathrm{x}$ number of plants in that grade) / (maximum grade $\mathrm{x}$ total number of assessed plants) $\mathrm{x} 100$

In vitro experiments:

Effect of bioagents on linear growth of $F$. oxysporum isolate:

Trichoderma hamatum and T. harzianum obtained from the Identification of Microorganisms Unit, Plant Pathol. Res. Inst., A.R.C were used to study the inhibitory effect of these antagonistic fungi on growth of $F$. oxysporum, the cause of pepper wilt. In this respect, Petri plates $(9 \mathrm{~cm}$-diameter) containing PDA were inoculated with disc $(5 \mathrm{~mm} \varnothing)$ of the Trichoderma isolates in one side of the plate and another disc $(5 \mathrm{~mm} \varnothing)$ of $F$. oxysporum at the opposite side. Three replicates were used for each particular treatment. Control plates inoculated with the pathogenic fungus only were prepared. Incubation was made at $25 \pm 2^{\circ} \mathrm{C}$ for $7-10$ days. The growth of each treatment was determined when the mycelial growth covered the medium surface of any plate. The reduction percentage was calculated using the following formula according to Abada and Ahmed (2014).

Where;

$$
\mathrm{I}=(\mathrm{C}-\mathrm{T}) / \mathrm{C} \mathrm{X} 100
$$

$\mathrm{I}=$ Percent of inhibition in growth of the tested pathogen.

$\mathrm{C}=$ Radial growth of the pathogen $(\mathrm{mm})$ in control.

$\mathrm{T}=$ Radial growth of the pathogen $(\mathrm{mm})$ in treatment.

Effect of resistance inducers on linear growth of $F$. oxysporum isolate:

Dipotassium phosphate $\left(\mathrm{K}_{2} \mathrm{HPO}_{4}\right)$, and potassium sorbate at three concentrations 2.0, 4.0 and $6.0 \%(\mathrm{w} / \mathrm{v})$; salicylic acid and ascorbic acid at concentration of $0.5,1.0$ and $2.0 \%(\mathrm{w} / \mathrm{v})$ and chitosan at concentration of $0.5,1.0$ and $2.0 \%(\mathrm{w} / \mathrm{v})$ were prepared. The chemicals were kindly provided by Sigma Company, Cairo-Egypt, to study their effects on growth of $F$. oxysporum isolate (El-Mougy et al., 2004). Chemicals were added individually to conical flasks containing sterilized PDA medium to obtain the desired concentrations, then mixed and dispensed in sterilized 
Petri dishes. The discs $(5 \mathrm{~mm} \emptyset)$ of $F$. oxysporum were transferred to the center of the PDA plates. Each treatment was replicated 3 times. Control treatment was made by inoculating a disc of $F$. oxysporum onto PDA medium in petri plate without any inducers. Incubation was made at $25 \pm 2^{\circ} \mathrm{C}$ for $7-10$ days. The diameters of colonies were measured as mentioned before.

Effect of plant oils on linear growth of F. oxysporum isolate:

The extracted oils from clove, mint and cumin plants were used to study their effect on the growth of $F$. oxysporum. The tested oils were brought from EL Captain Company for extracting natural oils and plants. Cairo, Egypt. Chloroform at a rate $2 \%$ was added to each of the concentrated plant oils to increase their solubility (Fahiem, 2010). Concentrations of $0.25,0.5$ and $1.0 \%$ of each oil were made and each was added to melted PDA medium. Then the poured plates were left to set up and an equal disc $(5 \mathrm{~mm} \varnothing)$ of $F$. oxysporum was put at the center. Three replicate plates were used for each treatment. Control treatment was in form of inoculated plates without adding any of the tested plant oils (Chloroform only). Inoculated plates were incubated at $25 \pm 2^{\circ} \mathrm{C}$ for $7-10$ days. The percentage of growth reduction of $F$. oxysporum was calculated as mentioned before.

In vivo experiments:

Effect of bioagents, resistance inducers, plant oils, biocides and fungicide on the severity of pepper wilt under greenhouse conditions:

The efficacy of chemical inducers selecting according to the best inhibitory concentration against the fungus in concern was experimented under greenhouse conditions. Dipotassium phosphate and potassium sorbate, salicylic acid, ascorbic acid, chitosan, three of plant oils in addition to T. hamatum and T. harzianum $\left(10^{7}\right.$ spore/ml) Abou-Zeid et al. (2003), Bio Arc ${ }^{\circledR}$ and Bio Zeid ${ }^{\circledR}$ are commercial biocides labeled on different crops in Egypt were tested along with Bio Nagi (Tricoderma asperellum) at rate of $2.5 \mathrm{~g} / \mathrm{L}$ (Mahmoud et al., 2013), that is first recorded in Egypt by Abou-Zeid and Mahmoud (2012) and still under registration. Types, active ingredients and rate of applications are shown in Table (1).

Table 1. Active ingredients of Trichoderma spp., chemical inducers, plant oils, biocides and a fungicide

\begin{tabular}{|l|c|c|c|}
\hline Tested products & Active ingredients & Types & Rate \\
\hline T. hamatum & T. hamatum & Fungus & $1 \times 10 \% / \mathrm{ml}$ \\
\hline T.harzianum & T.harzianum & Fungus & $1 \times 10 \% / \mathrm{ml}$ \\
\hline Dipotassium phosphate & $\mathrm{K}_{2} \mathrm{H} \mathrm{PO}_{4}$ & Salts & $2.0 \% \mathrm{w} / \mathrm{v}$ \\
\hline Potassium sorbate & $\mathrm{C}_{6} \mathrm{H}_{7} \mathrm{KO}_{2}$ & Salts & $2.0 \% \mathrm{w} / \mathrm{v}$ \\
\hline Salicylic acid & $\mathrm{C}_{7} \mathrm{H}_{6} \mathrm{O}_{3}$ & Acid & $0.5 \% \mathrm{w} / \mathrm{v}$ \\
\hline Ascorbic acid & $\mathrm{C}_{6} \mathrm{H}_{8} \mathrm{O}_{6}$ & Acid & $0.5 \% \mathrm{w} / \mathrm{v}$ \\
\hline Chitosan & Natural polysaccharide & Chemical & $2.0 \% \mathrm{w} / \mathrm{v}$ \\
\hline Clove oil & Eugenol, $90-95 \%$ & Oil & $0.5 \% \mathrm{w} / \mathrm{v}$ \\
\hline Mint oil & Menthol, $48 \%$ & Oil & $0.5 \% \mathrm{w} / \mathrm{v}$ \\
\hline Cumin oil & Cuminaldehyde & Oil & $0.5 \% \mathrm{w} / \mathrm{v}$ \\
\hline Bio-ARC & Bacillus megaterium $6 \%(\mathrm{w} / \mathrm{w})$ & Biocide & $2.5 \mathrm{~g} / \mathrm{L}$ \\
\hline Bio-Zeid & Trichoderma album $2.5 \%(\mathrm{w} / \mathrm{w})$ & Biocide & $2.5 \mathrm{~g} / \mathrm{L}$ \\
\hline Bio-Nagi & Trichoderma asperellum & Biocide & $2.5 \mathrm{~g} / \mathrm{L}$ \\
\hline Topsin-M $(70 \%)$ & Thiophanate-Methyl & fungicide & $1 \mathrm{~g} / \mathrm{L}$ \\
\hline
\end{tabular}

Egypt. J. Phytopathol., Vol. 44, No. 2 (2016) 
Pepper seedlings (cv. Anaheim-M) were soaked in the solutions of each treatment for 2 hours (El-Mohamedy et al., 2014) before planting in pots containing soil infested with $F$. oxysporum at the rate of 5\%. Three seedlings per/pot were transplanted and three pots were used for each treatment as replicates. Untreated pepper seedlings were planted in infested soil as control. The wilt severity was determined according to Silva and Bettiol (2005) as mentioned before.

The effect of bioagents, resistance inducers, and fungicide on disease severity and yield under field conditions:

Randomized block design was followed; planting was made on February of two successive seasons 2015 and 2016 in naturally infected field with the causal organism of pepper wilt, Giza Research Station. Seedlings were soaked in solutions of inducers for $6 \mathrm{hr}$. The field plots $\left(9 \mathrm{~m}^{2}\right)$ consisted of 3 rows of $3 \mathrm{~m}$ long and $1 \mathrm{~m}$ in between. One seedling/hill was sown with $50 \mathrm{~cm}$ apart between hills. Untreated seedlings were allowed to grow as control. Disease severity was recorded every 30 days interval for 3 months using a visual 1-6 scale according to Silva and Bettiol (2005). At the end of the growing season, 20 plants were randomly chosen from each treatment to determine some yield parameters as plant height $(\mathrm{cm})$, number of branches per plant, number of pods per plant and pod yield (g/plant) in the two successive seasons (2015 \& 2016).

Statistical Analysis:

Statistical Analysis was done using analysis of variance, (ANOVA) using Computer Statistical Package Assistant V.7.6 beta according to Silva and Azevedo (2009).

\section{Res u l t s}

Isolation and identification of the causal pathogen:

Six selected fungal isolates isolated from pepper plants, collected from different governorates i.e. Beni-Sweif, Kafr El-Sheikh, Dakahliya, Gharbiya, Sharkiya and Menofia were purified using the hyphal tip technique and then they were identified at the Unit of Identification of Micro-organisms, Plant Pathology Research Institute, A.R.C., Giza, Egypt, as Fusarium oxysporum.

Pathogenicity Test:

Data in Table (2) show the pathogenic ability of the tested isolates on cv. Anaheim-M pepper plants. The isolates varied in their ability to cause wilt on plants under greenhouse conditions.

Table 2. Pathogenicity test of $F$. oxysporum isolates on pepper plants under greenhouse conditions

\begin{tabular}{|c|c|c|c|c|}
\hline Isolate No. & Governorates & Locations & DSI \% & Virulent group \\
\hline F1 & Kafr El-Sheikh & Sedi-Selem & 55.00 & L \\
\hline F2 & Beni-Sweif & Beni-Sewif & 33.33 & L \\
\hline F3 & Dakahliya & Sinbellawein & 96.67 & H \\
\hline F4 & Gharbiya & Tanta & 71.67 & M \\
\hline F5 & Sharkiya & Hihia & 68.33 & M \\
\hline F6 & Menofia & Berkeh-El-Sabaa & 63.33 & L \\
\hline L.S.D at 5\% & & 4.64 & - \\
\hline
\end{tabular}


The most aggressive isolate was $F$. oxysporum (F3) isolated from Dakahliya which recorded $96.67 \%$ disease severity. Meanwhile, F. oxysporum (F2) caused the least disease severity, being $33.33 \%$.

Effect of resistance inducers, plant oils and bioagents on growth of F. oxysporum in vitro:

The inhibitory effect of antagonistic micro-organisms and plant resistance inducers on the growth of $F$. oxysporum was evaluated under in vitro. The results revealed that all treatments could drastically reduce the linear growth of the tested isolate (F3) of F. oxysporum.

Data in Table (3) indicate that all tested treatments reduced the growth of $F$. oxysporum on PDA plates compared with control. Concerning to chemical inducers and plant oils; it was found a positive relation between the high concentration of the resistance inducers and plant oils the recorded reduction of $F$. oxysporum growth. Clove oil at $0.25 \%$ showed complete inhibition of mycelial growth of $F$. oxysporum (100\%), followed by chitosan at $0.4 \%$ which gave $(98.8 \%)$ without significant differences. Salicylic acid at $0.1 \%$ gave the highest inhibitory effect $(92.2 \%)$.

Table 3. The effect of different resistance inducers, plant oils and bioagents on growth of $F$. oxysporum under laboratory conditions

\begin{tabular}{|l|c|c|c|}
\hline \multirow{3}{*}{ Treatments } & Conc. \% & $\begin{array}{c}\text { Linear growth } \\
(\mathrm{mm})\end{array}$ & $\begin{array}{c}\text { Growth reduction } \\
(\%)\end{array}$ \\
\hline \multirow{3}{*}{ Di Potassium phosphate } & 2.0 & 18.0 & 80.0 \\
\cline { 2 - 4 } & 4.0 & 13.0 & 85.5 \\
\cline { 2 - 4 } & 6.0 & 9.0 & 90.0 \\
\cline { 2 - 4 } & 2.0 & 22.0 & 75.5 \\
\cline { 2 - 4 } & 4.0 & 19.0 & 78.8 \\
\hline \multirow{3}{*}{ Salicylic acid } & 0.0 & 10.0 & 88.8 \\
\cline { 2 - 4 } & 0.05 & 12.0 & 86.6 \\
\cline { 2 - 4 } & 0.07 & 9.0 & 90.0 \\
\hline \multirow{3}{*}{ Ascorbic acid } & 0.05 & 7.0 & 92.2 \\
\cline { 2 - 4 } & 0.07 & 52.0 & 42.2 \\
\cline { 2 - 4 } & 0.1 & 17.0 & 81.1 \\
\hline \multirow{3}{*}{ Clove oil } & 0.1 & 14.0 & 84.4 \\
\cline { 2 - 4 } & 0.2 & 8.0 & 91.1 \\
\hline \multirow{3}{*}{ Mint oil } & 0.4 & 5.0 & 94.4 \\
\hline \multirow{3}{*}{ Cumin oil } & 0.25 & 1.0 & 98.8 \\
\cline { 2 - 4 } & 0.5 & 0.0 & 100 \\
\hline Thamatum & 1 & 0.0 & 100 \\
\hline T. harzianum & 0.25 & 0.0 & 57.7 \\
\hline Control (Chloroform) & 0.5 & 3.8 & 65.5 \\
\hline L.S.D. at 5\% & 1 & 3.1 & 72.2 \\
\cline { 2 - 4 } & 0.25 & 2.5 & 43.3 \\
\cline { 2 - 4 } & 0.5 & 5.1 & 46.6 \\
\cline { 2 - 4 } & 1 & 4.8 & 50.0 \\
\hline & & 4.5 & 91.1 \\
\hline & & 8.0 & 88.8 \\
\hline & & 10.0 & -0 \\
\hline
\end{tabular}

Egypt. J. Phytopathol., Vol. 44, No. 2 (2016) 
Meanwhile, cumin oil at $1.0 \%$ concentration gave the least inhibitory effect (50.0\%) compared with control treatment with Chloroform which had no effect on the linear growth of the pathogen. On the other hand, the antagonistic T. hamatum isolate showed greater inhibitory effect $(91.1 \%)$ compared with $T$. harzianum $(88.8 \%)$. However, the difference between the two antagonists was not significant.

Greenhouse testing:

Effect of bioagents, resistance inducers, plant oils, biocides and a fungicide on pepper wilt under greenhouse conditions:

All treatments significantly reduced severity of Fusarium wilt under greenhouse conditions as result of soaking pepper seedlings in solutions of inducers at the selected concentrations of dipotassium phosphate, potassium sorbate, salicylic, ascorbic acid and chitosan, along with clove, mint and cumin oils and bioagents $T$. hamatum and T. harzianum. Biocides Bio-Arc, Bio-Zeid and Bio-Nagi were experimented and the fungicide Topsin-M70 against pepper wilt caused by F.oxysporum compared with the untreated control plants.

Data presented in Table (4) indicate that the most effective treatments were BioZeid and salicylic acid which gave similar disease severity (DSI\%), being $21.67 \%$, followed by ascorbic acid, Bio-Nagi, T. hamatum and T. harzianum which decreased disease reading, being $26.67,33.33,38.33$ and $43.33 \%$ on the average, respectively. Meanwhile, cumin oil was the least effective one where it recorded $91.67 \%$ disease severity compared to the control. However, all tested inducers were less effective than Topsin-M70 in controlling pepper wilt which recorded $16.67 \%$ disease severity.

Table 4. Effect of bioagents, resistance inducers, plant oils, biocides and fungicide on the disease severity under greenhouse conditions

\begin{tabular}{|l|c|}
\hline Treatments & DSI \% \\
\hline T.hamatum & 38.33 \\
\hline T.harzianum & 43.33 \\
\hline Di Potassium phosphate & 50.00 \\
\hline Potassium sorbate & 89.47 \\
\hline Ascorbic acid & 26.67 \\
\hline Salicylic acid & 21.67 \\
\hline Clove oil & 56.20 \\
\hline Mint oil & 66.00 \\
\hline Cumin oil & 91.67 \\
\hline Chitosan & 55.00 \\
\hline Bio-Arc & 60.00 \\
\hline Bio-Zeid & 21.67 \\
\hline Bio-Nagi & 33.33 \\
\hline Topsin-M (70\%) & 16.67 \\
\hline Control & 100.00 \\
\hline L.S.D. at 5\% & 4.73 \\
\hline
\end{tabular}


Field experiments:

Effect of bioagents, resistance inducers, plant oils, biocides and the fungicide Topsin-M on pepper wilt under field conditions:

Data in Tables (5 and 6) show that all biotic and abiotic treatments significantly reduced disease severity compared to control treatment. In this respect, Bio-Zeid and salicylic acid showed the highest efficiency compared to the other treatments where they recorded 9.64 and $8.94 \%$ disease severity in the first season, respectively. While, salicylic acid recorded higher efficient than Bio-Zeid in the second season, being 7.79 and $7.92 \%$. Seedlings soaked in ascorbic acid, Bio-Nagi and T. hamatum came next to both of Bio-Zeid and salicylic acid and decreased disease severity to $11.16,13.44$ and $15.66 \%$ in the first season and $9.88,11.91$ and $13.87 \%$ in the second season, respectively. Cumin showed the lowest effect on wilt disease, so it recorded 29.33 and $26.71 \%$, as compared to control which recorded 37.64 and $33.33 \%$ in both seasons, respectively.

Table 5. Effect of bioagents, resistance inducers, plant oils, biocides and fungicide (Topsin-M) on pepper wilt and some plant parameters under field conditions in season 2015

\begin{tabular}{|l|c|c|c|c|c|}
\hline \multicolumn{1}{|c|}{ Treatments } & $\begin{array}{c}\text { DSI } \\
(\%)\end{array}$ & $\begin{array}{c}\text { Plant } \\
\text { height } \\
(\mathrm{cm})\end{array}$ & $\begin{array}{c}\text { No. of } \\
\text { branch/plant }\end{array}$ & $\begin{array}{c}\text { No. of } \\
\text { pods/plant }\end{array}$ & $\begin{array}{c}\text { Pod yield } \\
(\mathrm{gm}) / \text { plant }\end{array}$ \\
\hline T.hamatum & 15.66 & 56.21 & 4.6 & 23.84 & 433.81 \\
\hline T.harzianum & 24.19 & 53.57 & 4.4 & 18.21 & 331.43 \\
\hline Di Potassium phosphate & 17.88 & 55.32 & 5.0 & 20.46 & 372.38 \\
\hline Potassium sorbate & 28.90 & 47.79 & 4.6 & 17.40 & 276.67 \\
\hline Ascorbic acid & 11.16 & 58.75 & 4.5 & 24.39 & 443.81 \\
\hline Salicylic acid & 9.64 & 61.70 & 4.6 & 25.46 & 463.33 \\
\hline Chitosan & 20.16 & 52.89 & 4.5 & 18.94 & 344.76 \\
\hline Clove & 23.90 & 60.43 & 4.6 & 20.66 & 369.33 \\
\hline Mint & 22.46 & 56.20 & 4.7 & 17.66 & 297.86 \\
\hline Cumin & 29.33 & 48.60 & 4.5 & 15.98 & 285.81 \\
\hline Bio-Arc & 22.85 & 59.36 & 4.5 & 22.03 & 400.95 \\
\hline Bio-Zeid & 8.94 & 62.89 & 4.6 & 26.61 & 504.29 \\
\hline Bio-Nagi & 13.44 & 58.41 & 5.0 & 24.05 & 437.62 \\
\hline Topsin-M (70\%) & 6.72 & 61.59 & 4.5 & 28.99 & 547.62 \\
\hline Control & 37.64 & 41.41 & 4.4 & 15.06 & 234.10 \\
\hline L.S. D at 5\% & 1.75 & 2.52 & 1.24 & 1.79 & 15.08 \\
\hline
\end{tabular}

On the other side, a significant increase in plant height, number of branches/plant, number of pods/plant and pod yield $(\mathrm{gm}) /$ plant in seedling treatments with some biotic and abiotic inducers (Tables 5 and 6) was recorded. The most effective inducers were Bio-Zeid and salicylic acid followed by ascorbic acid, Bio-Nagi and T. hamatum, whereas the lowest treatment was potassium sorbate in both seasons. The results indicated that the highest pod yield/ plant was found in 
case of treatment with Bio-Zeid followed by those treated with salicylic acid, being 463.33 and $504.29 \mathrm{gm}$ at the first season, as well as, second season salicylic acid recorded the highest effect compared to Bio-Zeid, being 551.56 and $506.77 \%$. While the lowest yield was obtained from cumin treatments, being 285.81 and $299.80 \%$ in both seasons.

Table 6. Effect of bioagents, resistance inducers, plant oils, biocides and fungicide (Topsin-M) on pepper wilt and some plant parameters under field conditions in season 2016

\begin{tabular}{|l|c|c|c|c|c|}
\hline \multicolumn{1}{|c|}{ Treatments } & $\begin{array}{c}\text { DSI } \\
(\%)\end{array}$ & $\begin{array}{c}\text { Plant } \\
\text { height } \\
(\mathrm{cm})\end{array}$ & $\begin{array}{c}\text { No. of } \\
\text { branch/plant }\end{array}$ & $\begin{array}{c}\text { No. of } \\
\text { pods/plant }\end{array}$ & $\begin{array}{c}\text { Pod yield } \\
(\mathrm{gm}) / \text { plant }\end{array}$ \\
\hline T.hamatum & 13.87 & 59.63 & 4.7 & 26.69 & 474.48 \\
\hline T.harzianum & 21.43 & 56.82 & 5.0 & 20.39 & 362.50 \\
\hline Di Potassium phosphate & 15.83 & 57.62 & 4.3 & 22.91 & 407.29 \\
\hline Potassium sorbate & 25.60 & 51.75 & 4.6 & 19.27 & 302.60 \\
\hline Ascorbic acid & 9.88 & 61.26 & 4.5 & 27.30 & 485.42 \\
\hline Salicylic acid & 7.79 & 65.39 & 5.0 & 29.33 & 551.56 \\
\hline Chitosan & 17.86 & 55.05 & 4.5 & 21.21 & 377.08 \\
\hline Clove & 23.33 & 62.75 & 4.6 & 22.76 & 393.75 \\
\hline Mint & 22.82 & 57.72 & 4.7 & 19.95 & 345.10 \\
\hline Cumin & 26.71 & 51.20 & 4.5 & 17.33 & 299.80 \\
\hline Bio-Arc & 20.24 & 57.66 & 4.9 & 24.66 & 438.54 \\
\hline Bio-Zeid & 7.92 & 64.33 & 5.0 & 28.50 & 506.77 \\
\hline Bio-Nagi & 11.91 & 62.96 & 4.6 & 26.92 & 478.65 \\
\hline Topsin-M (70\%) & 5.95 & 64.65 & 5.0 & 30.88 & 598.96 \\
\hline Control & 33.33 & 43.93 & 4.4 & 16.44 & 262.30 \\
\hline L.S.D. at 5\% & 2.50 & 4.85 & 1.54 & 1.00 & 21.29 \\
\hline
\end{tabular}

\section{D i s c us s i o n}

Pepper plants are subject to infection with many diseases (Lamb et al., 1999; Utkhede and Mathur, 2005 and Demirci and Dolar, 2006), among which the soilborne diseases are the most important. Many fungi belonging to genera Fusarium, Macrophomina, Rhizoctonia, Pythium, Verticilium and Sclerotinia causing damping-off, root rot and wilt diseases are commonly encountered in the greenhouse, nurseries and fields (Liu and baker, 1980; Fletcher, 1994; Soner et al., 2005 and Goicoechea, 2006).

Results of the present study showed that isolated fungi from wilted pepper plants collected from six Governorates (Beni-Sweif, Kafr El-Sheikh, Dakahliya, Gharbiya, Sharkiya and Menofia) were identified as Fusarium oxysporum. The isolate F3 was highly pathogenic towards pepper plant caused $96.67 \%$ disease severity. Data are in accordance with those reported by Mushtaq and Hashmi (1997); Sahii and Khalid (2007). Moreover, the results revealed that all tested antagonistic micro-organisms could effectively decrease the linear growth of Fusarium oxysporum in vitro. Meanwhile T. hamatum isolate, showed superior inhibitory effect $(91.1 \%)$ against 
the growth of the pathogenic fungus compared, with T. harzianum, being $88.8 \%$. These results are in accordance with those previously reported by Sahii and Khalid (2007) who examined biocontrol of Fusarium oxysporum, the causal pathogen of pepper wilt, using different strains of antagonistic fungi of Trichoderma sp., in vitro. They observed considerable inhibition of the mycelial growth of pathogen as a response to the effect of Trichoderma sp. antagonism. The mechanism of biocontrol of plant pathogens using antagonists may be through competition for space and food or by stimulating host plant by inducing resistance to the pathogen, or antibiosis, as production of low molecular fungi toxic compounds or enzymes (Matar et al., 2009). The mechanism of biological control and the antagonistic relationship of microorganisms to the plant pathogens in general was studied by several authors (Cavagliery et al., 2005; Dubey et al., 2007; Guoj et al., 2004; Matar et al., 2009 and Sahii and Khalid, 2007).

Chitosan, salicylic acid and dipotassium hydrogen phosphate gave the highest inhibitory effect on mycelial growth of $F$. oxysporum. Many investigators used abiotic factors for induction of plant resistance against several diseases. Our results are in agreement with Ragab et al. (2012) who revealed that Chitosan caused complete reduction in growth of $F$. oxysporum the causal of pepper wilt (Capsicum annum L.). Similar results were recorded by many investigators with various crops. Chitin and chitosan as well the safe materials were reported to induce resistance by Abd-El-Kareem (2002). These findings in general agree with Özgönen et al. (2001) who stated that salicylic acid completely inhibited the mycelial development of $F$. oxysporum f. sp. lycopersici in vitro. As well as, clove gave complete inhibitory effect on growth of $F$. oxysporum followed by mint, while, cumin oil showed the lowest inhibitory activity in controlling $F$. oxysporum. These results are in agreement with Torre et al. (2016) who reported that the best results were obtained with clove oil and its major component eugenol in controlling $F$. oxysporum $\mathrm{f}$. sp. lycopersici, and those of Barrerea-Necha et al. (2009) who reported that $F$. oxysporum f. sp. gladioli was totally inhibited with clove oil. In the present study, it was clear that the tested treatments significantly reduced severity of Fusarium wilt under greenhouse conditions. The most effective treatments were Bio-Zeid and salicylic acid followed by Ascorbic acid, Bio-Nagi, T. hamatum and T. harzianum. Similar results were obtained by Al-Sohaibani et al. (2011) who reported that two biocides, Bio-Arc and Bio-Zeid were significantly effective in controlling root rot disease incidence of sweet basil and also pepper (Abdel-Monaim and Ismail, 2010) who reported that antioxidant compounds (coumaric acid, citric acid, propylgalate and salicylic acid each at 100 and $200 \mathrm{ppm}$ ) reduced wilt when used as seedling soaking under greenhouse and field conditions. All tested chemicals significantly increased plant height, plant branching and total yield per plant. Also, El- Hassan et al. (2013) reported that using $T$. hamatum delayed the time of infection by $F$. oxysporum, promoted the growth, and increased the dry weight of a susceptible variety of lentil. The percent of mortality was reduced to 33 and $40 \%$ when using $T$. hamatum, respectively, compared to $93 \%$ in the control treatment. Plant colonization results indicated that $T$. hamatum and its filtrate significantly $(\mathrm{p} \leq 0.05)$ reduced development of the pathogen in the vascular tissue of lentil to $<30$ and $<40 \%$ stem colonization, respectively. So, they suggested that potential biocontrol mechanisms 
of $T$. hamatum towards $F$. oxysporum f. sp. lentis were antibiosis by production of antifungal enzymes, complex mechanisms of mycoparasitism, competition for key nutrients and/or ecological niches, growth promotion, and a combination of these effects.

Also, in the present study, all the tested treatments reduced the area of the wilt under field conditions and increased the plant vigor and pod yield per plant in both seasons. In this respect, the most effective inducers were salicylic acid and Bio-Zeid followed by Ascorbic acid, Bio-Nagi and T. hamatum, whereas the lowest treatment was potassium sorbate in both seasons. These results are in agreement with AbdelMonaim and Ismail (2010) who reported that application of SA inhibits ethylene production leading to an increase in fruit number and consequently increases fruit yield per plant. Also, SAR mechanisms might be as a result of induce plant resistance (De Meyer et al., 1998), produce extracellular enzymes and antifungal or antibiotics, which decrease biotic stress on plant, and produce growth promoters substances (Szczech and Shoda, 2004). Also, Al-Sohaibani et al. (2011) reported that two biocides, Bio-Arc (Bacillus megaterium) and Bio-Zeid (Trichoderma album) were significantly effective in controlling root rot disease incidence.

\section{R e f e r e n c e s}

Abada, K.A. and Ahmed, M.A. 2014. Management fusarium wilt of sweet pepper by Bacillus strains. American J. Life Sci., 2(6-2): 19-25.

Abd-El-Kareem, F. 2002. Integrated treatments between bioagents and chitosan on root rot diseases of pea plants under field conditions. Egypt J. Appl. Sci., 17: 257-279.

Abdel-Monaim, M.F. 2010. Induced systemic resistance in tomato plants against fusarium wilt disease. pp:253-263. In Proceedings of the $2^{\text {nd }}$ Minia Conference for Agriculture and Environmental Science, 22-25 March, Minia, Egypt.

Abdel-Monaim, M.F. and Ismail, M.E. 2010. The use of antioxidants to control root rot and wilt diseases of pepper. Not. Sci. Biol., 2(2): 46-55.

Abou-Zeid, N.M.; Arafa, M.K. and Attia, S. 2003. Biological control of post emergence diseases of faba bean, lentil and chickpea in Egypt. Egypt. J. Agric. Res., 81(4): 1491-1503.

Abou-Zeid, N.M. El-Garhy, A.M. and Mokhtar, Sohir A. 2002. Biological and chemical control of root rot/wilt disease in some legume crops under greenhouse conditions in Egypt. Egypt. J. Agric. Res., 80(4): 1493-1501.

Abou-Zeid, N.M. and Mahmoud Noher, A. 2012. First record of Tricoderma asperellum in Egypt. Egypt. J. Phytopathol., 40(1), (Abstract).

Akram, W. and Anjum, T. 2011. Use of bioagents and synthetic chemicals for induction of systemic resistance in tomato against diseases. Int. Res. J. Agric. Sci. Soil Sci., 1: 286-292. 
Al-Sohaibani, S.A.; Mahmoud, M.A.; Al-Othman, Monira, R.; Ragab, Mona, M.M.; Saber, M.M. and Abd El- Aziz, Abeer, R.M. 2011. Influence of some biotic and abiotic inducers on root rot disease incidence of sweet basil. African $J$. Microbiol., Res., 5(22):3628-3639.

Barrerea-Necha, L.L.; Garduño-Pizaña, C. and Garcia-Barrera, L.J. 2009. In vitro antifungal activity of essential oils and their compounds on mycelial growth of $F$. oxysporum f. sp. gladioli. Plant Pathol., J., 8(1):17-21.

Booth, C. 1971. The genus Fusarium. Commonwealth Mycological Institute, Kew, Surrey, England.

Brewer, M.T. and Larkin, R.P. 2005. Efficacy of several potential biocontrol organisms against Rhizoctonia solani on potato. Crop Prot., 24: 939-950.

Cavagliery, L.; Orlando, J.; Rodriguez, M.I.; Chulze, S. and Etcheverry, M. 2005. Biocontrol of Bacillus subtilis against Fusarium verticillioides in vitro and at the maize root level. Res. Microbiol., 156: 748-754.

Chowdhury, M.S.N.; Hoque, F.; Mehraj, H. and Uddin, A.J. 2015. Vegetative growth and yield performance of four chilli (Capsicum frutescens) cultivars. American-Eurasian J. Agric. Environ. Sci., 15(4): 514-517.

De Meyer, G.; Bigirimana, J.; Elad, Y. and Höfte, M. 1998. Induced systemic resistance in Trichoderma harzianum T39 bio-control of Botrytis cinerea. Eur. J. Plant Pathol., 104: 279-286.

Demirci, F. and Dolar, F.S. 2006. Effects of some plant materials on phytophthora blight (Phytophthora capsici Leon.) of pepper. Turk. J. Agric., 30:247-252.

Domsch, K.H.; Gams, W. and Anderson, T.H. 1980. Compendium of Soil Fungi. Vol. 1 and 2, Academic Press. London.

Dubey, S.C.; Suresh, M. and Singh, B. 2007. Evaluation of Trichoderma species against Fusarium oxysporum f. sp. ciceris for integrated management of chickpea wilt. Biological Control, 40:118-127.

El-Hassan, S.A.; Gowen, S.R. and Pembroke, B. 2013. Use of Trichoderma hamatum for biocontrol of lentil vascular wilt disease: Efficacy, Mechanisms of Interaction and Future Prospects. J. Pl. Prot. Res., 53(1):12-26.

El-Khallal, S.M. 2007. Induction and modulation of resistance in tomato plants against fusarium wilt disease by bioagent fungi (arbuscular mycorrhiza) and/or hormonal elicitors (jasmonic acid and salicylic acid): 1- changes in growth, some metabolic activities and endogenous hormones related to defense mechanism. Australian J. Basic Appl. Sci., 1: 691-705.

El-Mohamedy, R.S.R.; Jabnoun-Khiareddine, H. and Daami-Remadi, M. 2014. Control of root rot diseases of tomato plants caused by Fusarium solani, Rhizoctonia solani and Sclerotium rolfsii using different chemical plant resistance inducers. Tunisian J. Pl., Prot., 9: 45-55. 
El-Mohamedy, S.R.; Abdel-Kader, M.M.; Abd- El-Kareem, F. and El-Mougy, Nehal, S. 2013. Essential oils, inorganic acids and potassium salts as control measures against the growth of tomato root rot pathogens in vitro. J. Agric. Technol., 9: 1507-1520.

El-Mougy, Nehal, S. 1995. Studies on wilt and root rot diseases of tomato in Egypt and their control by modern methods. M.Sc. Thesis, Faculty of Agriculture, Cairo University, Egypt, 162 p.

El-Mougy, Nehal, S.; Abd-El-Karem, F.; El-Gamal, N.G. and Fotouh Y.O. 2004. Application of fungicides alternatives for controlling cowpea root rot diseases under greenhouse and field conditions. Egypt. J. Phytopathol., 32: 23-35.

Fahiem, M.A. 2010. Studies on Bean Fruit in Egypt. M.Sc. Thesis, Fac. Agric., Benha Univ., 121 p.

Fletcher, J.T. 1994. Fusarium stem and fruit rot of sweet peppers in the glasshouse. Plant Pathology, 43:225-227.

Goicoechea, N. 2006. Verticillium induced wilt in pepper: Physiological disorders and perspectives for controlling the disease. Plant Pathol., J., 5(2):258-265.

Guoj, H.; Qih, Y.; Guoy, H.; Geh, L.; Gong, L.Y.; Zhang, L.X. and Sunp, H. 2004. Biocontrol of tomato wilt by plant growth-promoting rhizobacteria. Biol. Control, 29: 66-72.

Hulang, H.C. 1980. Control of Sclerotinia wilt of sunflower by hyperparasites. Canadian J. Pl., Pathol., 2: 26-32.

Karlidag, H.; Yildirim, E. and Turan, M. 2009. Exogenous applications of salicylic acid affect quality and yield of strawberry grown under anti frost heated greenhouse conditions. J. Plant Nutr., Soil Sci., 172: 270-276.

Kucuk, C. and Kivanc, M. 2003. Isolation of Trichoderma spp. and determination of their antifungal, biochemical and physiological features. Turkish J. Biol., 27: 247-253.

Lamb, E.M.; Sonoda R.M., Oxman E.F. and Curry J.E. 1999. Identification and incidence of fusarium stem rot in greenhouse peppers in south Florida. Proc. Fla. State Hort. Soc., 112:308-309.

Lefebvre, V. and Palloix, A. 1996. Both epistatic and additive effects of QTLs are involved in polygenic induced resistance to disease: A case study the interaction pepper-Phytophthora capsici Leonian. Theor. App. Gen., 93: 503-511.

Liu, S.D. and Baker, R. 1980. Mechanism of biological control in soil suppressive to Rhizoctonia solani. Phytopathology, 70: 404-412.

Mahmoud, Noher, A.; Khalifa, M.M.A. and Abou-Zeid, N.M. 2013. Performance of some bio-fungicides on the most onion economic disease compared to recommended fungicide in Egypt. Egypt. J. Appl. Sci., 28:66-92. 
Mandal, S.; Mallick, N. and Mitra, A. 2009. Salicylic acid- induced resistance to Fusarium oxysporum f. sp. lycopersici in tomato. Plant Physiol. Biochem., 47: 642-649.

Matar, S.M.; El-Kazzaz, S.A.; Wagih, E.E.; El-Diwany, A.I.; Moustafa, H.E.; AboZaid, G.A.; Abd-Elsalam, H.E. and Hafez, E.E. 2009. Antagonistic and inhibitory effect of Bacillus subtilis against certain plant pathogenic fungi. $J$. Biotechnol., 8(1): 53-61.

Metwally, M.M. 2004. Resistance induction against disease of faba bean crop. Ph.D. Thesis, Fac. Agric., Cairo University, Egypt, 94 p.

Mushtaq, M. and Hashmi M.H. 1997. Fungi associated with wilt disease of Capsicum in Sindh, Pakistan. Pak. J. Bot., 29(2):217-222.

Özgönen, H.; Biçici, M. and Erkiliç A. 2001. The effect of salicylic acid and endomycorrhizal fungus Glomus etunicatum on plant development of tomatoes and Fusarium wilt caused by Fusarium oxysporum f. sp. lycopersici. Turk. J. Agric. For., 25:25-29.

Ragab, Mona M.M., Ashour, A.M.A., Abdel-Kader, M. M., El-Mohamady, R. and Abdel-Aziz, A. 2012. In vitro evaluation of some fungicides alternatives against Fusarium oxysporum the causal of wilt disease of pepper (Capsicum annum L). Int. J. Agric., Forestry, 2(2):70-77.

Sahii, I.Y. and Khalid A.N. 2007. In vitro biological control of Fusarium oxysporum causing wilt in Capsicum annum. Mycopath., 5(2):85-88.

Silva, F.A. and Azevedo, C.A. 2009. Principal components analysis in the software assistat-statistical attendance. In: World Congress on Computers in Agriculture, 7, Reno-NV-USA: American Soc. Agric. and Biol. Eng.

Silva, J.C. and Bettiol, W. 2005. Potential of non-pathogenic Fusarium oxysporum isolates for control of Fusarium wilt of tomato. Fitopatologia Brasileira, 30: 409-412.

Soylu, S.; Soylu, M.; Kurt, S. and Ekici O.K. 2005. Antagonistic potentials of rhizosphere associated bacterial isolates against soil-borne diseases of tomato and pepper caused by Sclerotinia sclerotiorum and Rhizoctonia solani. Pakistan J. Biol., Sci., 8(1):43-48.

Szczech, M. and Shoda, M. 2004. Biocontrol of Rhizoctonia damping-off of tomato by Bacillus subtilis combined with Burkholderia cepacia. J. Phytopathol., 152 549-556.

Torre, A.L.; Caradonia, F.; Matere, A. and Battaglia, V. 2016. Using plant essential oils to control Fusarium wilt in tomato plants. Eur. J. Plant Path., 144: 487-496.

Utkhede, R.S. and Mathur S. 2005. Biological and chemical control of fruit rot in greenhouse sweet peppers (Capsicum annum L.) caused by Fusarium subglutinans. J. Biol. Sci., 5(5):610-615. 
Waller, J.M. 1981. Fungal pathogen in the air and in plant shoots. Rev. PI. Pathol., 60: $153-160$.

Zaher, Effat A.; Abada, K.A. and Zyton, Marwa A. 2013. Effect of combination between bioagents and solarization on management of crown-and stem-rot of Egyptian clover. J. Plant Sci., 1(3):43-50.

Zahra, S.H.; Amin, B. and Mehdi, Y. 2010. The salicylic acid effect on the tomato (Lycopersicum esculentum Mill.) germination, growth and photosynthetic pigment under salinity stress $(\mathrm{NaCl})$. J. Stress Physiol., Biochem., 6:4-16.

(Received 20/10/2016; in revised form 25/11/2016) 


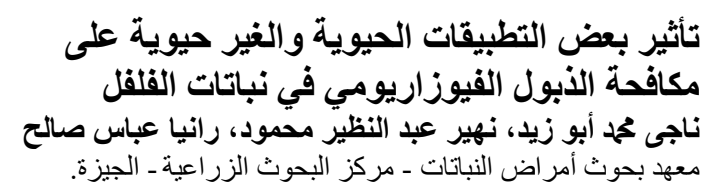

تم عزل ست عزلات من الفطر فيوزاريوم اكسيسبورم المعزولة من نباتات

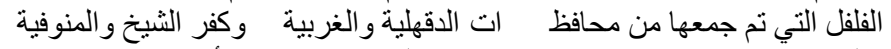

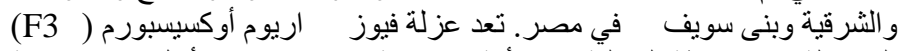

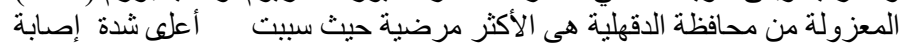

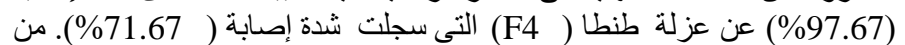

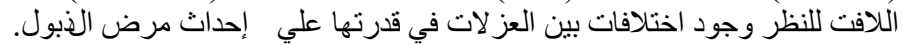

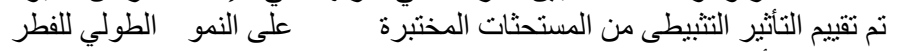

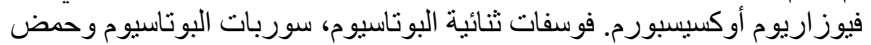

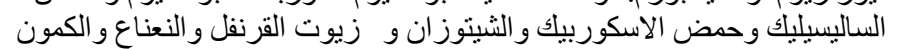

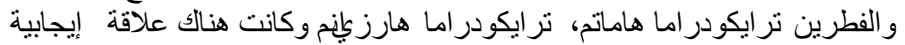

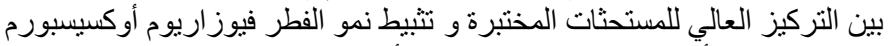

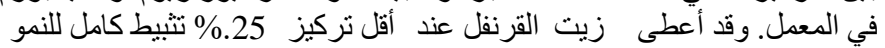

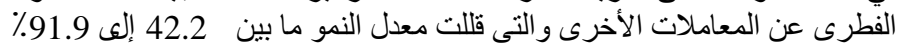

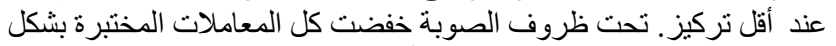

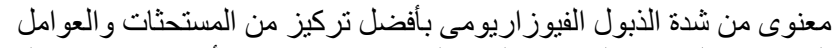

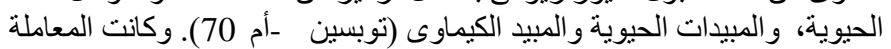

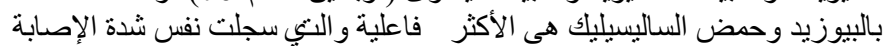

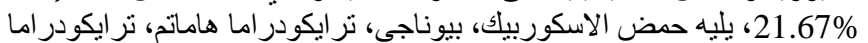

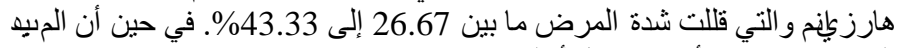

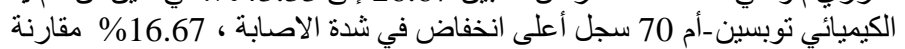

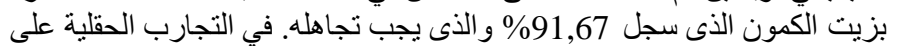

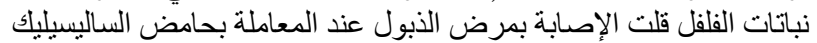

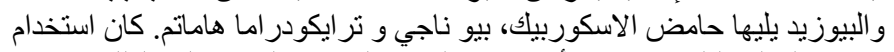

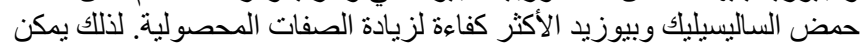

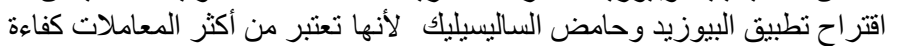

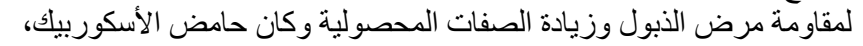
وهذا

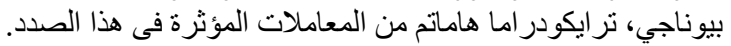

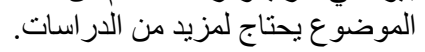

Egypt. J. Phytopathol., Vol. 44, No. 2 (2016) 